\title{
Rapid transport and high accumulation of amorphous silica in the Congo deep-sea fan: A preliminary budget
}

\author{
Raimonet Mélanie ${ }^{1,{ }^{*}}$, Ragueneau Olivier ${ }^{1}$, Jacques Vincent ${ }^{1}$, Corvaisier Rudolph ${ }^{1}$, \\ Moriceau Brivaëla ${ }^{1}$, Khripounoff Alexis ${ }^{2}$, Pozzato Lara ${ }^{3,4}$, Rabouille Christophe ${ }^{3,4}$
}

${ }^{1}$ Inst Univ European Mer, UMR CNRS UBO IRD IFREMER 6539, Lab Sci Environm Marin, F-29280

Plouzane, France.

2 IFREMER, Lab Environm Profond, F-29280 Plouzane, France.

3 UMR CEA CNRS UVSQ, Lab Sci Climat \& Environm, F-91190 Gif Sur Yvette, France.

${ }^{4}$ IPSL, F-91190 Gif Sur Yvette, France.

*Corresponding author : Mélanie Raimonet, email address : melanie.raimonet@gmail.com

\begin{abstract}
:
Mechanisms controlling the transfer and retention of silicon ( $\mathrm{Si}$ ) along continental margins are poorly understood, but play a major role in the functioning of coastal ecosystems and the oceanic biological pump of carbon. Deep-sea fans are well recognized as carbon sink spots, but we lack knowledge about the importance of the fans in the global Si cycle. Here, we provide a first estimate of the role played by the Congo deep-sea fan, one of the biggest in the world, in the Si cycle. Sediment cores sampled in the deep-sea fan were analyzed to build a Si mass balance. An exceptionally high accumulation rate of amorphous silica aSiO(2) $(2.29+/-0.58 \mathrm{~mol} \mathrm{Si} \mathrm{m(-2)} \mathrm{y(-1))} \mathrm{was} \mathrm{found,} \mathrm{due} \mathrm{to} \mathrm{a} \mathrm{high} \mathrm{sedimentation} \mathrm{rate}$ and the presence of aluminum in the sediments. Although favored by bioirrigation, recycling fluxes remained low $(0.3 \mathrm{~mol} \mathrm{Si} \mathrm{m}(-2) \mathrm{y}(-1))$ and reconstructed input fluxes could only be explained by lateral inputs coming from the canyon. Preliminary calculations show that the rapid transport of aSiO(2) through the canyon and the excellent preservation efficiency in the sediments imply that $50 \%$ of aSiO(2) river inputs from the Congo River accumulate annually in the deep-sea fan. Si:C ratios in deep-sea fan sediments were very low (0.2) and only three times as high as those measured in the river itself, which suggests that material from the river and the continental shelf was delivered directly through the canyon, with very little time for $\mathrm{Si}$ and $\mathrm{C}$ cycle decoupling to take place.
\end{abstract}

\section{Highlights}

Amorphous silica intensively flows through the submarine canyon to the Congo deep-sea fan. Turbidite currents lead to the highest silica burial rates ever found in oceanic areas. Burial in the deep-sea fan accounts for $>50 \%$ of the amorphous silica riverine flux. Low Si:C ratios highlight fast particle transfer and weak decoupling between Si and C cycles.

Keywords : Continental margin, Land-sea export, Silica cycle, Congo canyon, Deep-sea fan 


\section{Introduction}

Better understanding of the fate of riverine silicon ( $\mathrm{Si}$ ) during its transit towards the ocean is essential, as $\mathrm{Si}$ is one of the limiting factors for diatom growth in aquatic systems. Diatoms are the main primary producers in coastal and oceanic waters (Nelson et al., 1995; Tréguer et al., 1995). In many coastal regions, in particular upwelling areas, diatoms constitute the basis of the most productive food chains (Cushing, 1989) and sustain intense fisheries. In the open ocean, diatoms contribute to up to $40 \%$ of global primary production (Nelson et al., 1995; Tréguer et al., 1995). They play a key role in the biological pump of carbon, thanks to the ballast role played by the diatom frustules, to the capacity of diatoms to form aggregates and to the fact that diatoms are food of choice for large zooplankton which expels the remains of the algae via fecal pellets. All these mechanisms produce in fact rapidly sinking particles that can escape degradation in surface waters (Ragueneau et al., 2006; Moriceau et al., 2009). Diatom dynamics are therefore pivotal to the functioning of continental margin ecosystems, but require Si. By limiting diatom blooms, the availability of $\mathrm{Si}$ affects other biogeochemical cycles, including those of nitrogen and carbon (Froelich et al., 1992; Chai et al., 2002; Street-Perrott and Barker, 2008). Given the importance of Si in the functioning of coastal and oceanic ecosystems, quantifying Si inputs and understanding the processes that control the transfer of $\mathrm{Si}$ along continental margins, including retention in estuaries and continental shelves, is necessary to calculate a global Si budget (Dürr et al., 2011).

The majority of Si inputs to continental margins derive from land (Tréguer et al., 1995; Tréguer and De La Rocha, 2013). For a long time, it was thought that the only Si inputs into the ocean were in the form of dissolved $\mathrm{Si}(\mathrm{dSi})$, which is produced by the weathering of silicate rocks (Meybeck, 1982). Although this phenomenon remains a major contributor to the discharge of terrigenous $\mathrm{Si}$, several complementary mechanisms have been discovered. It has been shown that $16-40 \%$ of the total Si export flux is in the particulate form (Conley, 1997; Smis et al., 2010; Dürr et al., 2011), in turn constituted mainly by amorphous silica $\left(\mathrm{aSiO}_{2}\right)$ derived from river diatoms, phytoliths or amorphous soils. 
Moving from land to sea on continental margins, Si molecules undergo several cycles of production/dissolution and adsorption/desorption on suspended particles, both in surface waters and at the sediment-water interface (Ragueneau et al., 2010). On continental margins, abiotic reverse weathering converts dissolved to particulate Si (Mackenzie and Garrels, 1966; Mackenzie and Kump, 1995; Michalopoulos and Aller, 1995, 2004), strongly impacting the $\mathrm{C}$ cycle due to $\mathrm{CO}_{2}$ release (Mackenzie and Garrels, 1966). After revising the Antarctic Si budget, DeMaster (2002) showed that continental margins may become the missing Si sink to maintain Si biogeochemical cycle at steady state, implying that $\mathrm{Si}$ and $\mathrm{C}$ cycles were less decoupled than previously thought. In addition, it has been demonstrated that several anthropogenic perturbations such as eutrophication (Schelske and Stoermer, 1971; Conley et al., 1993) and damming (Humborg et al., 1997), as well as the proliferation of invasive species of bivalves (Ragueneau et al., 2002, 2005), may directly or indirectly alter Si transfer and retention, with important implications at short and long time scales for the functioning of coastal ecosystems and the input of Si to the global ocean.

If the transfer of $\mathrm{Si}$ from land to coastal waters is poorly understood, the exchange of $\mathrm{Si}$ between the margin and the open ocean is even less studied. Recently, Ragueneau et al. (2009) reported a direct input of Si from the margin to the deep sediments on the Congo system, suggesting that downslope sediment transport may be of global significance. No information however exists on the burial capacity of $\mathrm{Si}$ in deep sea fans or on the transfer of Si by active submarine canyons that fuel the fans.

Deep sea fans constitute the second largest global sink of atmospheric carbon (Galy et al., 2007; Covault, 2011) and the Congo deep-sea fan is one of the biggest in the world. This system is a major carbon burial region in the North Atlantic, with organic matter being directly discharged in the ocean by the associated canyon (Rabouille et al., 2009) and the Congo River being the second largest riverine source of Si to the ocean (Gaillardet et al., 1999). This suggests that the transfer of $\mathrm{Si}$ through the canyon could also be significant, leading to high global Si burial in the Congo deep-sea fan. 
The aims of this paper are to give a first estimation of silica accumulation in the Congo deepsea fan, to discuss the role of biological processes on the benthic Si cycle, to establish a tentative budget of benthic $\mathrm{Si}$ cycling, especially sediment-water exchange of $\mathrm{SiO}_{2}$, and to examine the role of the canyon in the rapid transport of riverine material to the deep ocean. The global role of submarine canyons and deep sea fans in Si delivery and storage in the deep ocean is also discussed.

\section{Material and methods}

\subsection{Description of study area and sampling strategy}

The Congo margin, and more specifically the terminal lobes of the Congo deep-sea fan, are a unique area in the world ocean. The lobes are fuelled quasi-continuously by turbidites containing a large proportion of labile organic matter delivered by the Congo River (the second largest river in the world by its freshwater discharge; Milliman, 1991). The annual sediment load from the Congo River is $4810^{6} \mathrm{t} \mathrm{yr}^{-1}$ (Covault et al., 2011) and its

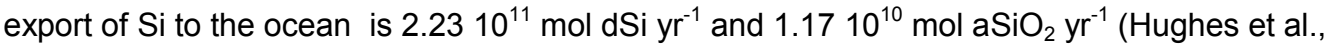
2011). The existence of a connection between the Congo River and its submarine canyon is a unique feature (Babonneau et al., 2002a), since all other large rivers (i.e. Amazon, Yangtze, Mississippi) are disconnected from their canyons due to the increase of sea level which followed the last interglacial periods. The absence of disconnection in spite of sea water rise in the Congo system must be explained by a sediment load overwhelming the capacity of sediment accumulation on the continental shelf (Covault, 2011), as well as longshore Northward drift, and canyon-flank instabilities caused by episodic hyperpycnal flow due to flooding (Savoye et al., 2009). High-energy turbidity currents ensure a massive transfer of particles through the canyon and channel system (Savoye et al., 2009) from the 
river mouth to the deep-sea fan, which displays the same features as a river delta, i.e. fresh terrestrial organic matter inputs and high burial rate (Burdige, 2005).

The sampling area is located on the lobe complex, which covers an area of about $3000 \mathrm{~km}^{2}$ and expands between $4800 \mathrm{~m}$ and $5200 \mathrm{~m}$ water depth at the outlet of the Congo submarine canyon, $750 \mathrm{~km}$ off the coast.

Samples were collected during the WACS 2011 cruise between February 20 and 25, 2011. Four sediment cores were sampled (Fig. 1) using the Remote Operated Vehicle (ROV) Victor 6000 (Ifremer). Their denomination and exact location are reported in Table 1. The core PL435 was sampled in the upper lobe (site A), PL436 and PL437 in the central part of the lobe (site C) and PL438 at the end of the lobe (site D). Three benthic chambers of the respirometer RAP were deployed to measure total benthic fluxes at site A (RAP3, close to PL435) and at site C (RAP4, close to PL436).

\subsection{Sample processing}

The cores were processed immediately after recovery in the cold room on board the ship at $+5^{\circ} \mathrm{C}$. Overlying water of each core was sampled using a syringe. Cores were sliced at 0.5 $\mathrm{cm}$ intervals in the first $2 \mathrm{~cm}$, at $1 \mathrm{~cm}$ intervals down to $10 \mathrm{~cm}$ and at $2 \mathrm{~cm}$ intervals between 10 and $20 \mathrm{~cm}$. Sediment slices were placed in tubes and immediately centrifuged for 20 minutes at $3500 \mathrm{rpm}$. Sediments were then stored at $-20^{\circ} \mathrm{C}$ until aSiO ${ }_{2}$ concentrations were analyzed in the laboratory. Overlying and pore waters were filtered through Millex filters $(0.22$ $\mu \mathrm{m}$ pore size) and stored at $+4^{\circ} \mathrm{C}$ until dSi analysis were performed. dSi flux through the sediment-water interface was measured in situ inside the benthic chambers carried by the respirometer RAP (an autonomous lander equipped with three cylindric benthic chambers each 30-cm in diameter; for a detailed description, see Khripounoff et al., 2006). The functioning principle of the benthic chambers is to isolate and incubate a known volume of seawater in close contact with the enclosed sediment surface area. Three sampling cells, 
positioned within each chamber, enable water sample collection $(100 \mathrm{~mL})$ at predetermined time intervals for later calculation of fluxes. Water samples were taken at the beginning of the incubation (T0), after 7h (T1), 13h (T2) and 19h (T3). Immediately after recovery, the sampling cells were removed from the chambers and the water samples collected by gravity flow in separate vials.

\subsection{Analytical methods}

Overlying and pore water dSi concentrations were measured using the colorimetric method of Tréguer and Le Corre (1975).

$\mathrm{aSiO}_{2}$ concentrations in sediments have been calculated (see section 2.4) using a modified version of the Si-Al method developed by Köning et al. (2002). This method consists of the simultaneous measurement of $\mathrm{Si}$ and $\mathrm{Al}$ concentrations during an alkaline digestion (90 minutes, $\mathrm{NaOH}, 0.5 \mathrm{M})$. The method was adapted to allow a larger amount of samples to be analyzed within a day, without losing its robustness. The continuous measurement of $\mathrm{Si}$ and Al concentrations was replaced by a multiple measurements done every minute during one hour of alkaline digestion. This required adaptation of the method of Aminot and Kerouel (2007) for the measurement of dSi concentrations during alkaline digestions, optimizing the sampling and rinsing time on the autoanalyzer. Accuracy was tested with standard solutions. Al concentrations were measured using the Lumogallion fluorescence method developed by Hydes and Liss (1976).

\subsection{Calculation of benthic $\mathrm{aSiO}_{2}$ concentrations, $\mathrm{aSiO}_{2}$ burial and benthic dSi fluxes}

$\mathrm{Si}$ and $\mathrm{Al}$ digestion curves were fitted in order to determine $\mathrm{aSiO}_{2}$ concentrations in sediments, and distinguish $\mathrm{aSiO}_{2}$ from lithogenic $\mathrm{Si}$. Four models were applied to the $\mathrm{Si}$ and Al digestion curves, going from a single phase (model 1), two phases (model 2), three phases (model 3), and a continuum of phases (model 4) of $\mathrm{aSiO}_{2}$ in the sediments (see 
Köning et al., 2002). One example of digestion curves and model application is shown in Figure 2. The Figure 3 shows two vertical profiles of $\mathrm{aSiO}_{2}$ calculated by two different methods: the model 1 with only one $\mathrm{aSiO}_{2}$ phase (Köning et al., 2002), and the best statistical adjustment which most often corresponded to model 2 or model 3 of Köning et al. (2002). The best statistical adjustment is determined with the Log Likelihood method (Hilborn and Mangel, 1997). The statistical criteria is defined by:

$$
\log (L)=-\frac{N}{2} \log \left(\frac{\sum\left(\log \left(\hat{C}_{j}\right)-\log \left(C_{j}\right)\right)^{2}}{N}\right)
$$

$N$ is the number of measurements $j$ for one sample. $C_{j}$ is the concentration measured at each point $j . \hat{C}_{j}$ is the concentration calculated with the model at each point $j$. A more complex model improves the fit if the $\log (L)$ is at least two units higher for each added parameter.

$\mathrm{aSiO}_{2}$ concentrations are expressed as the percentage of weight $\left(\% \mathrm{gDW} \mathrm{g}{ }^{-1}\right)$ and noted as $\%$. For each model, $\mathrm{aSiO}_{2}$ concentrations are calculated following the equations detailed in Köning et al. (2002). This method provides very robust results of $\mathrm{aSiO}_{2}$ concentrations. This also provides useful information on the quality of the silica studied (see Section 3.1.).

Burial rates of $\mathrm{aSiO}_{2}\left(\mathrm{~mol} \mathrm{~m}^{-2} \mathrm{y}^{-1}\right)$ were estimated using the following formula:

$$
\text { burial }=\omega(1-\phi)\left[a \mathrm{SiO}_{2}\right]_{\infty} M M^{-1}
$$

$\omega$ is the linear sedimentation rate estimated by ${ }^{210} \mathrm{~Pb}_{\mathrm{xs}}$ below the bioturbation zone between 5 and $20 \mathrm{~cm}$ depth (0.019 $\mathrm{m} \mathrm{y}^{-1}$; Rabouille et al., 2009). This value was determined in the same lobe area in December 2003 and was used to extrapolate carbon burial for the whole lobe area (Rabouille et al., 2009). This value was in agreement with the large sedimentation rates that occurred in the upper part of the lobes over the last century (Savoye et al., 2009).

$\Phi$ is porosity, assumed to be 0.7 from preliminary measurements. 
$\left[a \mathrm{SiO}_{2}\right]_{\infty}$ is the mean $\mathrm{aSiO}_{2}$ concentration $\left(\mathrm{gDW} \mathrm{aSiO}_{2} \mathrm{~g}^{-1}\right)$ in deep sediment layers (10-20 $\mathrm{cm}$ depth), taken from the best adjustment model. The $\mathrm{aSiO}_{2}$ concentration strongly decreased between 0 and $10 \mathrm{~cm}$ depth but did not vary much below $10 \mathrm{~cm}$ depth. The $\mathrm{aSiO}_{2}$ concentration was thus averaged between 10 and $20 \mathrm{~cm}$ to smooth vertical discontinuities.

$\mathrm{MM}$ is the molar mass of $\mathrm{aSiO}_{2}\left(66 \mathrm{~g} \mathrm{~mol}^{-1}\right)$.

Total benthic dSi fluxes were calculated using the benthic Si model developed by Raimonet (2011). Concentrations of $\mathrm{aSiO}_{2}$ and dSi were used to adjust the model and estimate fluxes. The specificity of this model is to incorporate two $\mathrm{aSiO}_{2}$ phases, and to represent bioirrigation in addition to the processes of dissolution and reprecipitation already described by Khalil et al. (2007). This model allowed calculating benthic dSi fluxes and deconvoluting diffusion and bioirrigation fluxes. Total fluxes measured with benthic chambers were used to validate our estimates.

\section{Results}

The best adjustment of dSi concentrations during $\mathrm{aSiO}_{2}$ digestion was generally achieved with models 2 and 3 (representing two and three $\mathrm{aSiO}_{2}$ phases) rather than with model 1 (one $\mathrm{aSiO}_{2}$ phase; see an example in Figure 2).

Figure 3 displays the downcore profiles of $\mathrm{aSiO}_{2}$ estimated using the model 1 and the best adjustment model. Sediment $\mathrm{aSiO}_{2}$ concentrations, estimated using the model 1, were quasiconstant downcore and ranged between 2 and $4.5 \%$. Only the PL438 profiles exhibited a rapid decrease of $\mathrm{aSiO}_{2}$ concentrations with depth, from 5-6 \% at the sediment surface to 2-3 $\%$ below $4 \mathrm{~cm}$ depth. The best adjustment $\mathrm{aSiO}_{2}$ profiles exhibited a more variable evolution with depth, with peaks reaching up to $7-8 \%$, never observed in the model 1 profiles. The best adjustment profiles showed maximal values (up to 6-8 \%) at $2.5 \mathrm{~cm}$ (PL435 and PL437), 4.5 $\mathrm{cm}$ (PL436), and between 6 and $9 \mathrm{~cm}$ (PL438). 
Distinct trends of $\mathrm{dSi}$ and $\mathrm{aSiO}_{2}$ profiles were observed depending on sites. $\mathrm{aSiO}_{2}$ concentrations showed an exponential decrease with depth down to $10 \mathrm{~cm}$ depth (where vertical discontinuities are absent) at site $D$ (PL438) while quasi vertical profiles were observed at sites A and C (Figure 3 ). An exponential increase of dSi concentrations, typically encountered in deep sea sediments, was observed at site D whereas this gradient was not observed in the first 5 to $10 \mathrm{~cm}$ at sites $A$ and $C$ (Figure 4). In addition, asymptotic concentrations, i.e. dSi concentrations in deep sediments, were different at sites A and D $\left(190-270 \mu \mathrm{mol} \mathrm{I}^{-1}\right)$ and at sites $\mathrm{C}\left(570-620 \mu \mathrm{mol} \mathrm{I}^{-1}\right)$.

The fitting of dSi and $\mathrm{aSiO}_{2}$ profiles with the benthic Si model (Figure 5) allowed to determine bioirrigation rates and calculate total (diffusion + bioirrigation) benthic fluxes. Bioirrigation rates were lower at site $A\left(0.003 \mathrm{~h}^{-1}\right)$ compared to site $C\left(0.005-0.01 \mathrm{~h}^{-1}\right)$, while irrigation depth were higher (10 versus 6.5-7 cm). The total (diffusion + bioirrigation) fluxes remained in a small range between 0.24 and $0.38 \mathrm{~mol} \mathrm{Si} \mathrm{m}^{-2} \mathrm{y}^{-1}$ with a mean value at $0.30 \mathrm{~mol} \mathrm{Si} \mathrm{m}^{-2} \mathrm{y}^{-}$ ${ }^{1}$ (Table 2). Estimates of total fluxes by the modelling approach were validated by the measurements in benthic chambers (Figure 6; Table 2) at site A (modelled: $0.24 \mathrm{~mol} \mathrm{Si} \mathrm{m}^{-2} \mathrm{y}^{-}$ 1; measured: $0.14-0.18 \mathrm{~mol} \mathrm{Si} \mathrm{m}^{-2} \mathrm{y}^{-1}$ ) and site $\mathrm{C}$ (modelled: $0.32 \mathrm{~mol} \mathrm{Si} \mathrm{m}{ }^{-2} \mathrm{y}^{-1}$; measured: 0.08-0.34 mol Si m $\left.{ }^{-2} \mathrm{y}^{-1}\right)$.

\section{Discussion}

\section{1. $\quad \mathrm{aSiO}_{2}$ concentrations in sediments}

Benthic $\mathrm{aSiO}_{2}$ concentrations ranging from 2 to $8 \%$ are in the same range as those measured in the continental margin off the Congo River (Ragueneau et al., 2009). These values are also typically observed in other margins, such as the North Carolina, Long Island Sound, California borderlands (DeMaster, 2002) or the Bay of Brest (Ragueneau et al., 2005). They are however much lower than those found in the Peru margin or within the Gulf 
of California (10-20 \%; DeMaster, 2002) and off Antarctica (20-49\%; DeMaster et al., 1996), where high values are due to high diatom production. They are however much higher than the extreme low values found off the Amazon River (close to 0.5\%; DeMaster, 1991). The difference between the Congo and the Amazon is mostly explained by the very high sediment loads of the former (600-1150 Tg SPM, 20-40 times the SPM flux of the Congo; Coynel et al., 2005; $\mathrm{Ni}$ et al., 2008) which dilute $\mathrm{aSiO}_{2}$ concentrations in both suspended matter (0.96\%; Conley, 1997), and in benthic sediments (0.5\%; DeMaster, 1991). Even if the Congo is the world's second largest river in terms of water discharge, it is only the twelfth in annual SPM flux (Coynel et al., 2005). Therefore, the higher benthic $\mathrm{aSiO}_{2}$ concentrations measured off the Congo River (2-8 \%; this study) might at least partly be explained by the lower SPM flux and the higher $\% \mathrm{aSiO}_{2}$ in suspended matter (9.3\%; Conley, 1997).

The best adjustment of dSi concentrations during $\mathrm{aSiO}_{2}$ digestion achieved with models 2 and 3 (representing 2 and $3 \mathrm{aSiO}_{2}$ phases) rather than with model $1\left(1 \mathrm{aSiO}_{2}\right.$ phase), suggests the presence of multiple phases of $\mathrm{aSiO}_{2}$, as already shown for other systems (Gallinari et al., 2002; Van Cappellen et al., 2002; Khalil et al., 2007; Moriceau et al., 2009). The presence of maximal $\mathrm{aSiO}_{2}$ concentrations at specific sediment depths using the multiphasic model may correspond to the sedimentation of a less reactive phase of $\mathrm{aSiO}_{2}$. While this low reactive phase belongs to the $\mathrm{aSiO}_{2}$ fraction using the multiphasic model, it appears as lithogenic silica with the monophasic model (model 1) which may thereby underestimate the true $\mathrm{aSiO}_{2}$ concentration.

The origin of such a low reactive phase of $\mathrm{aSiO}_{2}$ remains unclear. It could be created during in situ early diagenesis in sediments: it is well established that the presence of Al strongly affects both the solubility (Van Cappellen and Qiu, 1997a) and the reactivity (Van Cappellen and Qiu, 1997b) of biogenic silica and the sediments of the Congo deep sea fan are particularly Al-enriched. Al was shown to substitute Si within diatom frustules and to create an Al-rich opal, which was evidenced out off the Congo River (Van Bennekom et al., 1989). Another mechanism that might provide low reactivity $\mathrm{aSiO}_{2}$ could be the transient loads of 
low reactive biogenic matter brought by turbiditic currents in the canyon and deposited in the deep sea fan. This might be linked to (1) the seasonal variations of riverine $\mathrm{aSiO}_{2}$ quantity and composition: high $\mathrm{aSiO}_{2}$ flux dominated by diatoms in low water conditions, and low $\mathrm{aSiO}_{2}$ flux dominated by phytoliths and sponge spicules in high water conditions (Hughes et al., 2011), and/or (2) the resuspension of sediments settled on the continental shelf. A better characterization of the biogenic matter present in the Congo deep-sea fan is therefore needed to confirm its origin.

Whatever the origin of this phase, the comparison between monophasic and multiphasic $\mathrm{aSiO}_{2}$ models (Figure 3) allowed us to detect its presence. In the following discussion, only data obtained with the best adjustment model will be used, in particular to estimate the $\mathrm{aSiO}_{2}$ accumulation rate, because this allows us to account for all $\mathrm{aSiO}_{2}$ phases, including this low reactivity phase which may be missed by monophasic $\mathrm{aSiO}_{2}$ models. As differences in $\mathrm{aSiO}_{2}$ concentrations were mostly observed in surface sediments layers and not in deeper ones (this study), deep $\mathrm{aSiO}_{2}$ concentrations, and thus burial rates, were not impacted by the analytical methods used for $\mathrm{aSiO}_{2}$ concentration determination $( \pm 0.2 \%)$.

\subsection{Si stocks in deep sea fan sediments: importance of biological and diagenetic processes}

The shape of dSi profiles at sites A and C is typical of bioirrigation (Aller, 1980; Forja and Gómez-Parra, 1998). In fact, using a benthic model describing $\mathrm{aSiO}_{2}$ early diagenesis and accounting for bioirrigation was required to fit dSi profiles at sites $\mathrm{A}$ and $\mathrm{C}$ (Figure 5). Fitting $\mathrm{aSiO}_{2}$ and dSi profiles by adjusting biorrigation rates and depths allows determining bioirrigation parameters and fluxes at the sediment-water interface. Irrigation rates (0.003$\left.0.01 \mathrm{~h}^{-1}\right)$ are in the range of values determined by inverse modeling in the literature (0.004$0.4 \mathrm{~h}^{-1}$; Meile et al., 2001) and in the high range of values measured in shallow estuarine sediments of the Puget Sound (0.0004-0.002 $\mathrm{h}^{-1}$; Emerson et al., 1984). The sites A and $\mathrm{C}$ 
displayed high bioirrigation rates, consistent with the observations of sparse Vesicomyidae at site $\mathrm{A}$, and the combination of more abundant Vesicomyidae and bacterial mats at site $\mathrm{C}$.

In addition, the differences in asymptotic dSi concentrations observed at the three different sites can be explained by different processes. The first explanation to account for the low asymptotic dSi concentrations at sites $A$ and $D$ is the presence of an Al-rich opal, evidenced by Van Bennekom et al. (1989) in the deep sea fan. Van Cappellen and Qiu (1997a,b) confirmed the importance of aluminum (Al) in the control of $\mathrm{aSiO}_{2}$ thermodynamic and kinetic dissolution properties. Whether this Al-rich opal originates in the Congo River itself, or Al is incorporated in the opal during early diagenesis remains unclear. But an important question remains with this hypothesis: what would explain the much higher asymptotic dSi concentrations in the central part of the deep sea fan, at site C? Why would there be less Al in the central part of the lobe, leading to a higher solubility? More data on Al concentrations at different stations of the lobes would be needed to confirm this hypothesis.

Other reasons could explain such different asymptotic dSi concentrations. The presence of bacterial mats at site $\mathrm{C}$ may have enhanced the degradation of organic matter, thereby favoring the dissolution of $\mathrm{aSiO}_{2}$. Different intensity of organic matter degradation might lead to $\mathrm{pH}$ changes which are also known to affect $\mathrm{aSiO}_{2}$ solubility (Van Cappellen and Qiu, 1997a). This factor is however unlikely to explain spatial variations of asymptotic dSi concentrations in the deep-sea fans because the $\mathrm{pH}$ range found in benthic sediments only affects the solubility by a factor of 5-10\% (Van Cappellen and Qiu, 2007a). Higher accumulation rates in the central part of the lobes (site C) could also lead to higher asymptotic dSi concentrations because of lower time for ageing and reprecipitation to happen (Ragueneau et al., 2000). The most likely hypothesis to explain asymptotic dSi concentrations is based on the presence of benthic macrofauna at sites A and C (unpublished data). The presence of macrofauna may have a retroactive effect on $\mathrm{aSiO}_{2}$ dissolution and explain the observed dSi profiles. Bioirrigation indeed increases exchanges at the sediment-water interface and thus the flux of oxygen and nitrate into sediments. The 
enhanced influx of oxidants generally increases the degradation of organic matter (Heilskov et al., 2006), which is known to favor the dissolution of $\mathrm{aSiO}_{2}$. Thus, we hypothesize that different bioirrigation activities may be responsible for different organic matter degradation and $\mathrm{aSiO}_{2}$ dissolution in these sediments causing differences in dSi asymptotic concentrations. At site A, where Vesicomyidae are sparse, the asymptotic concentration of $\mathrm{dSi}$ is $270 \mu \mathrm{mol} \mathrm{^{-1 }}$, whereas site $\mathrm{C}$ with numerous Vesicomyidae has an asymptotic concentration of 570 and $620 \mu \mathrm{mol} \mathrm{I}^{-1}$.

\subsection{Construction of a benthic Si mass balance in the deep sea fan}

Total (diffusion + bioirrigation) dSi fluxes at the sediment-water interface are similar to those measured on the shelf of the Congo ( 0.30 and $0.60 \mathrm{~mol} \mathrm{Si} \mathrm{m}^{-2} \mathrm{y}^{-1}$; Ragueneau et al., 2009) or off the Oman margin (Köning et al., 2002). They are 2 to 3 times higher than in the Pacific Ocean (McManus et al., 1995) and one order of magnitude higher than those at other sites in the North Atlantic such as BATS (Sayles et al., 1996) and NABE (Ragueneau et al., 2001). Fluxes are however lower in our study than in the Southern Ocean (DeMaster et al., 1996; Nelson et al., 2002) where benthic dSi concentrations are much higher.

Using a mean value for the total benthic dSi fluxes of $0.30 \pm 0.06 \mathrm{~mol} \mathrm{Si} \mathrm{m}^{-2} \mathrm{y}^{-1}$, it is possible to build a preliminary Si budget for the Congo deep sea fan. Based on the average concentrations of $\mathrm{aSiO}_{2}$ in the deep sediment layers (reported in section 3.1) and the accumulation rate of $0.019 \mathrm{~m} \mathrm{y}^{-1}$ previously measured in the Congo deep-sea fan (Rabouille et al., 2009), we estimated a burial flux of $2.29+/-0.58 \mathrm{~mol} \mathrm{Si} \mathrm{m}^{-2} \mathrm{y}^{-1}$ (Table 3). This rate is one to three orders of magnitude higher than in other oceanic regions, where estimates of $\mathrm{aSiO}_{2}$ burial range between 0.001 and $0.420 \mathrm{~mol} \mathrm{Si} \mathrm{m}^{-2} \mathrm{y}^{-1}$ (Table 3; see Ragueneau et al., 2002 and references therein). Our estimates are 7-13 times higher than those calculated upstream of the lobes, e.g. in the Congo deep submarine channel (BIOZAIRE/D; Ragueneau et al., 2009) and out of Congo influence (BIOZAIRE/C; Ragueneau et al., 2009). These 
differences are, at least partly, explained by much higher sedimentation rates in the lobes than on the continental shelf and slope (0.019 versus $0.001 \mathrm{~m} \mathrm{y}^{-1}$; Rabouille et al., 2009; Ragueneau et al., 2009). The high accumulation rate observed in the lobes confirms that lobes are similar to estuarine deltas, lagoons or inshore continental shelves, where high accumulation takes place (DeMaster et al., 1985; Nichols, 1989; Burdige, 2005). Moreover, the burial rate of $\mathrm{aSiO}_{2}$ observed in the lobes is similar to rates observed in some shallow coastal areas or ponds.

The benthic recycling and burial fluxes calculated above allowed estimating the deposition rates necessary to achieve a mass balance. The reconstructed deposition flux, obtained by assuming a steady state and adding the burial and benthic recycling fluxes, reaches $2.59 \mathrm{~mol}$ Si $m^{-2} y^{-1}$. A similarly high reconstructed deposition rate is observed only in the Southern Ocean (DeMaster et al., 1996). As in the Southern Ocean, the reconstructed deposition flux is 20-40 times higher than the deposition flux measured by means of sediment traps deployed in the Congo fan area (0.07-0.11 mol Si m ${ }^{-2} \mathrm{y}^{-1}$; Ragueneau et al., 2009). In the Southern Ocean, the mismatch between measured and reconstructed $\mathrm{aSiO}_{2}$ deposition fluxes could be attributed to sediment focusing due to bottom currents (DeMaster, 2002). Off the Congo shelf, sediment transport along the continental slope and excess accumulation of $\mathrm{aSiO}_{2}$ at the rise were suggested to provide the lateral inputs necessary to close the $\mathrm{Si}$ budget, a process which may be of significance also for the global input of $\mathrm{Si}$ from land to ocean (Ragueneau et al., 2009). Because the deep sea fan is far from the continental slope and because it is directly under the influence of the Congo canyon, it is most probable that the lateral inputs of $\mathrm{aSiO}_{2}$ necessary to close the $\mathrm{Si}$ budget come from the canyon itself, which is still very active (Babonneau et al., 2002).

The burial flux, extrapolated to the whole deep-sea fan $\left(3000 \mathrm{~km}^{2}\right)$, reaches $0.69+/-0.18$ $10^{10} \mathrm{~mol} \mathrm{Si} \mathrm{y}^{-1}$. This is a first approximation, because more measurements of sedimentation rates are needed to improve the estimation of the silica sink per se. The value used is however consistent with high sedimentation rates that occurred in the upper part of the lobes 
over the last century (Savoye et al., 2009). It is interesting to compare this first approximation of burial flux to riverine inputs. The burial flux represents $59 \%$ of the Congo River $\mathrm{aSiO}_{2}$ flux, estimated at $1.1710^{10} \mathrm{~mol} \mathrm{Si} y^{-1}$ by Hughes et al. (2011). This is very high, compared to the mean value of $20 \%$ found in estuaries (DeMaster, 1981). Interestingly, this number is similar to the one estimated for marginal and regional seas, as important interceptors of $\mathrm{aSiO}_{2}$ delivery to the open ocean (46\%; Dürr et al., 2011). Even if the origin of the sediment needs to be confirmed, especially to determine to what extent the material is directly transported from the river to the lobes, the high percentage of $\mathrm{aSiO}_{2}$ also suggests its effective preservation in the deep-sea fans. This phenomenon may be linked to (1) low recycling, most likely due to the presence of Al-rich opal in this region (Van Bennekom et al., 1989), (2) high deposition rates due to the presence of the canyon (see below) or (3) any combination of the two. Indeed, we have seen in this section that benthic recycling fluxes, although favored by biological processes, are not exceptionally high in that area where deposition fluxes and stocks of $\mathrm{aSiO}_{2}$ in the sediments are high. In addition, it is well established that sediment preservation efficiency of $\mathrm{aSiO}_{2}$ increases exponentially with sedimentation rates (Ragueneau et al., 2000).

\subsection{Si and $C$ coupling on the Congo margin and deep sea fan}

Following the revision of the Si budget in the different sectors of Antarctica (Pondaven et al., 2000; Hoppema et al., 2001; Nelson et al., 2002), it became obvious that silica accumulation has been overestimated in the sediments below the Antarctic Circumpolar Current. To maintain a marine Si budget at equilibrium, another sink for $\mathrm{aSiO}_{2}$ was needed and DeMaster (2002) provided strong arguments that continental margins may be the missing marine silica sink. In this scenario, the Si and C cycles would be more coupled than previously thought. It is therefore very interesting to explore the degree of coupling between the Si and C cycles off the Congo River and in its deep sea fan. 
Rabouille et al. (2009) estimated the carbon burial in the Lobe region at $0.4 \mathrm{Tg} \mathrm{C} \mathrm{y}^{-1}$, or 3.3 $10^{10} \mathrm{~mol} \mathrm{C} \mathrm{y}^{-1}$. This represents a major sink for carbon, accounting for some $22 \%$ of the total accumulation in the North Atlantic and $2-4 \%$ of the global carbon burial. $\mathrm{aSiO}_{2}$ accumulation

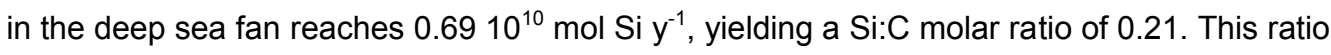
is three times lower than the minimal ratio measured in deep sea sediments (0.6-39; Ragueneau et al., 2002). Such a value suggests that the material accumulating in the deep sea fan does not derive from overlying surface waters. In fact, the Si:C ratio is generally between 30 and 300 lower in primary production-derived material in surface waters than the ratio measured in material accumulating in the underlying sediments (Ragueneau et al., 2002), reflecting the slower recycling of Si compared to C. This would imply a Si:C ratio in the range $0.001-0.01$ never encountered in primary production material. The $\mathrm{aSiO}_{2}$ transported to the deep-sea fans might rather originate from freshwater diatoms (Hughes et al., 2011) as well as amorphous river matter and marine diatoms grown on the continental margin. However, considering the high lateral flux from the Congo River and the low vertical flux in open waters, freshwater diatoms and amorphous river matter might dominate and it is therefore most interesting to explore the evolution of the $\mathrm{Si}: \mathrm{C}$ ratio from its origin in the river, to the fan area.

The Congo River delivers 1.9 $\mathrm{Tg} \mathrm{C} \mathrm{y}^{-1}$, or $15.810^{10} \mathrm{~mol} \mathrm{C} \mathrm{y^{-1 }}$ (Seyler et al., 2006). With a Si input of $1.17 \mathrm{~mol} \mathrm{Si} \mathrm{y}^{-1}$ as $\mathrm{aSiO}_{2}$ (Hughes et al., 2011), the $\mathrm{Si}: \mathrm{C}$ ratio at the river output is close to 0.07 . The Si:C ratio consequently increases only by a factor of three between the river and the fan sediments, which highlights that the Si and C cycles might only be slightly decoupled in the Congo system. The Si:C ratio in the deep-sea fan is also three times lower than the mean ratio of 0.6 calculated on continental margins (DeMaster, 2002). Rapid transport through the canyon does not seem to allow the typical Si:C decoupling due to a faster degradation of carbon observed elsewhere. This suggests that riverine loads might dominate and that the load of marine diatoms and older sediments temporally stored on the continental shelf might have been low. Nevertheless respective contributions of each source 
still need to be quantified. It might also be that biogenic silica and organic carbon preservation are intimately linked. It is well known that the organic matter coating opal surfaces protects silica from dissolution, until bacteria remove this coating (Bidle and Azam, 1999). More recently, it has been demonstrated that the degradation of the organic matter inside diatoms is also dependent upon the dissolution of the diatom frustules (Moriceau et al., 2009). Therefore, we hypothesize that the excellent preservation of the biogenic silica brought by the river (see Section 3.3), both through high sedimentation rates and the presence of Al in the sediments, also favors the excellent preservation of the organic matter in the deep sea fan region.

\section{Conclusions}

The Congo deep-sea fan is a very special area, in the sense that it is a deep ocean deposit that is directly related to the inputs from the $2^{\text {nd }}$ world largest river through an active canyon. The establishment of a benthic Si mass balance in the fan allows demonstrating that the vast majority of the $\mathrm{aSiO}_{2}$ deposited in that area comes from the Congo River through this canyon. Accumulation of $\mathrm{aSiO}_{2}$ is high, thanks to a high sedimentation rate. Opal accumulation strongly depends upon sedimentation rates, but in that area enriched with Al, our preliminary measurements indicate that early diagenetic processes most probably combine with this high sedimentation rate to explain the intensity of the accumulation as well as the fact that a large fraction of $\mathrm{aSiO}_{2}$ river inputs (50\%) may be preserved in the fan sediments. Clearly, larger spatial coverage and refined sedimentation rates are needed to ascertain these budgets. Studying Si:C ratios highlights the tight coupling between Si and C cycles during the transport of material from land to ocean through the canyon. We suggest that such linkage - already evidenced in pelagic waters, with mutual protection - also takes place in sediments and that it is worth developing a coupled model of $\mathrm{Si}$ and $\mathrm{C}$ early diagenesis to explore further this hypothesis. 
To our knowledge, this is the first exploration of the role played by canyons in the direct transfer of Si from land to ocean. If the Congo canyon does represent a unique system by its deposition and burial intensity, it would be most interesting (1) to improve these estimations for this region by refining sedimentation rates in the deep sea fan, (2) to determine the origin of the $\mathrm{aSiO}_{2}$ buried in the deep-sea fan by characterizing the origin and reactivity of the material buried in the fan, and (3) to explore other canyons and derive an estimate of the importance of this process at the global scale. Our results in the Congo deep-sea fan are important for the understanding of deltas, as deep-sea fans are deltas located in deep oceans. While in shallow deltas, biogenic $\mathrm{Si}$, as well as organic matter, is stored and recycled on the continental shelf, a large amount of Si escapes the continental shelf and is directly brought to the deep ocean in the case of submarine deltas (i.e. deep-sea fans). The location of biogenic matter storage and recycling areas has then important implications for the productivity of the coastal and ocean ecosystem.

\section{Acknowledgments}

We sincerely thank the N/O Pourquoi pas? captain and crew and all the participants of the WACS cruise which was led by K. Olu. We are very grateful to the two anonymous reviewers and the guest editor Kay Emeis for constructive remarks that significantly improved the manuscript, and to the leader guest and co-editors Kon-Kee Liu and Wolfgang Fennel who invited to submit our work. 


\section{References}

Aller, R.C., 1980. Quantifying solute distributions in the bioturbated zone of marine sediments by defining an average microenvironment. Geochim. Cosmochim. Acta 44(12), 1955-1965.

Aminot, A., Kerouel, R., 2007. Dosage automatique des nutriments dans les eaux marines methodes en flux continu. Ifremer, Quae Editions.

Babonneau, N., Savoye, B., Cremer, M., Klein, B., 2002. Morphology and architecture of the present canyon and channel system of the Zaire deep-sea fan. Mar. Petroleum Geol. 19(4), $445-467$.

Bidle, K.D., Azam, F., 1999. Accelerated dissolution of diatom silica by marine bacterial assemblages. Nature 397(6719), 508-512.

Burdige, D.J., 2005. Burial of terrestrial organic matter in marine sediments: A reassessment. Global Biogeochem. Cycles, 19(4), DOI: 10.1029/2004GB002368.

Chai, F., Dugdale, R.C., Peng, T.-H., Wilkerson, F.P., Barber, R.T., 2002. One-dimensional ecosystem model of the equatorial Pacific upwelling system. Part I: model development and silicon and nitrogen cycle. Deep Sea Res. II: Topical Studies in Oceanography, The Equatorial Pacific JGOFS Synthesis 49, 2713-2745.

Conley, D.J., 1997. Riverine contribution of biogenic silica to the oceanic silica budget. Limnol. Oceanogr. 42(4), 774-777.

Conley, D.J., Schelske, C.L., Stoermer, E.F., 1993. Modification of silica biogeochemistry with eutrophication in aquatic systems. Mar. Ecol. Prog. Ser. 101, 179-192.

Covault, J.A., 2011. Submarine fans and canyon-channel systems: a review of processes, products and models. Nature Education Knowledge 3(10), 4. 
Coynel, A., Seyler, P., Etcheber, H., Meybeck, M., Orange, D., 2005. Spatial and seasonal dynamics of total suspended sediment and organic carbon species in the Congo River. Global Biogeochem. Cycles 19(4), DOI: 10.1029/2004GB002335.

Cushing, D.H., 1989. A difference in structure between ecosystems in strongly stratified waters and in those that are only weakly stratified. J. Plankton Res. 11(1), 1-13.

DeMaster, D.J., 1981. The supply and accumulation of silica in the marine environment. Geochim. Cosmochim. Acta 45(10), 1715-1732.

DeMaster, D.J., 2002. The accumulation and cycling of biogenic silica in the Southern Ocean: revisiting the marine silica budget. Deep Sea Res. II: Topical Studies in Oceanography 49(16), 3155-3167.

DeMaster, D.J., McKee, B.A., Nittrouer, C.A., Jiangchu, Q., Guodong, C., 1985. Rates of sediment accumulation and particle reworking based on radiochemical measurements from continental shelf deposits in the East China Sea. Cont. Shelf Res. 4(1), 143-158.

DeMaster, D.J., McKee, B.A., Moore, W.S., Nelson, D.M., Showers, W.J., Smith Jr., W.O., 1991. Geochemical processes occurring in the waters at the Amazon River/ocean boundary. Oceanogr. 4(1), 15-20.

DeMaster, D.J., Ragueneau, O., Nittrouer, C.A. 1996. Preservation efficiencies and accumulation rates for biogenic silica and organic $\mathrm{C}, \mathrm{N}$, and $\mathrm{P}$ in hig-latitude sediments: the Ross Sea. J. Geophys. Res. 101 (C8), 18501-18518.

Dürr, H.H., Meybeck, M., Hartmann, J., Laruelle, G.G., Roubeix, V., 2011. Global spatial distribution of natural riverine silica inputs to the coastal zone. Biogeosciences 8(3), 597620.

Emerson, S., Jahnke, R., Heggie, D., 1984. Sediment-water exchange in shallow water estuarine sediments J. Mar. Res. 42, 709-730. 
Forja, J.M., Gómez-Parra, A., 1998. Measuring nutrient fluxes across the sediment-water interface using benthic chambers. Mar. Ecol. Prog. Ser. 164, 95-105.

Froelich, P.N., Blanc, V., Mortlock, R A., Chillrud, S.N., Dunstan, W., Udomkit, A., Peng, T.H., 1992. River fluxes of dissolved silica to the ocean were higher during glacials: Ge/Si in diatoms, rivers, and oceans. Paleoceanography 7(6), 739-767.

Gaillardet, J., Dupré, B., Louvat, P., Allègre, C.J., 1999. Global silicate weathering and CO2 consumption rates deduced from the chemistry of large rivers. Chem. Geol. 159, 3-30.

Gallinari, M., Ragueneau, O., Corrin, L., DeMaster, D.J., Treguer, P., 2002. The importance of water column processes on the dissolution properties of biogenic silica in deep-sea sediments I. Solubility. Geochim. Cosmochim. Acta 66(15), 2701-2717.

Galy, V., France-Lanord, C., Beyssac, O., Faure, P., Kudrass, H., Palhol, F., 2007. Efficient organic carbon burial in the Bengal fan sustained by the Himalayan erosional system. Nature $450,407-410$.

Heilskov, A.C., Alperin, M., Holmer, M., 2006. Benthic fauna bio-irrigation effects on nutrient regeneration in fish farm sediments. J. Exp. Mar. Biol. Ecol. 339(2), 204-225.

Hilborn, R., Mangel, M., 1997. The Ecological Detective: Confronting Models with Data. Princeton University Press, Princeton.

Hoppema, M., Klatt, O., Roether, W., Fahrbach, E., Bulsiewicz, K., Rodehacke, C., Rohardt, G., 2001. Prominent renewal of Weddell Sea Deep Water from a remote source. J. Mar. Res. 59(2), 257-279.

Hughes, H.J., Sondag, F., Cocquyt, C., Laraque, A., Pandi, A., André, L., Cardinal, D., 2011. Effect of seasonal biogenic silica variations on dissolved silicon fluxes and isotopic signatures in the Congo River. Limnol. Oceanogr. 56(2), 551-561. 
Humborg, C., Ittekkot, V., Cociasu, A., Bodungen, B.V., 1997. Effect of Danube River dam on Black Sea biogeochemistry and ecosystem structure. Nature 386(6623), 385-388.

Hydes, D.J., Liss, P.S., 1976. Fluorimetric method for the determination of low concentrations of dissolved aluminium in natural waters. Analyst 101(1209), 922-931.

Khalil, K., Rabouille, C., Gallinari, M., Soetaert, K., DeMaster, D.J., Ragueneau, O., 2007. Constraining biogenic silica dissolution in marine sediments : A comparison between diagenetic models and experimental dissolution rates. Mar. Chem. 106(1-2), 223-238

Khripounoff, A., Caprais, J.C., Crassous, P., 2006. Geochemical and biological recovery of the disturbed seafloor in polymetallic nodule fields of the Clipperton-Clarion Fracture Zone (CCFZ) at 5000m depth. Limnol. Oceanogr. 51, 2033-2041.

Köning, E., Epping, E., Van Raaphorst, W., 2002. Determining biogenic silica in marine samples by tracking silicate and aluminium concentrations in alkaline leaching solutions. Aquat. Geochem. 8(1), 37-67.

Mackenzie, F.T., Garrels, R.M., 1966. Chemical mass balance between rivers and oceans. Am. J. Sci. 264, 507-525.

Mackenzie, F.T., Kump, L.R., 1995. Reverse Weathering, Clay Mineral Formation, and Oceanic Element Cycles. Science 270, 586-586.

McManus, J., Hammond, D.E., Berelson, W.M., Kilgore, T.E., DeMaster, D.J., Ragueneau, O.G., Collier, R.W., 1995. Early diagenesis of biogenic opal : Dissolution rates, kinetics, and paleoceanographic implications. Deep Sea Res. II: Topical Studies in Oceanography 42, 871-903.

Meybeck, M., 1982. Carbon, nitrogen, and phosphorus transport by world rivers. Am. J. Sci. 282(4), 401-450.

Michalopoulos, P., Aller, R. C., 1995. Rapid clay mineral formation in Amazon delta sediments: reverse weathering and oceanic elemental cycles. Science 270(5236), 614-617. 
Michalopoulos, P., Aller, R.C., 2004. Early diagenesis of biogenic silica in the Amazon delta: alteration, authigenic clay formation, and storage. Geochim. Cosmochim. Acta 68, 10611085.

Milliman, J.D., 1991. Flux and fate of fluvial sediment and water in coastal seas, in: Mantoura, R.F.C., Martin, J.-M., Wollast, R. (Eds.), Ocean Margin Processes in Global Change. John Wiley and Sons, New York, pp. 69-89.

Moriceau, B., Goutx, M., Guigue, C., Lee, C., Armstrong, R., Duos, M., Tamburini, C., Charrière, B., Ragueneau, O., 2009. Si-C interactions during degradation of the diatom Skeletonema marinoi. Deep Sea Res. II: Topical Studies in Oceanography 56(18), 13811395.

Nelson, D., Tréguer, P., Brzezinski, M., Leynaert, A., Queguiner, B., 1995. Production and dissolution of biogenic silica in the ocean: Revised global estimates, comparison with regional data and relationship to biogenic sedimentation. Global Biogeochem. Cycles 9(3), 359-372.

Nelson, D.M., Anderson, R.F., Barber, R.T., Brzezinski, M.A., Buesseler, K.O., Chase, Z., Collier, R.W., Dickson, M.-L., François, R., Hiscock, M.R., Honjo, S., Marra, J., Martin, W.R., Sambrotto, R.N., Sayles, F.L., Sigmon, D.E., 2002. Vertical budgets for organic carbon and biogenic silica in the Pacific sector of the Southern Ocean, 1996-1998. Deep Sea Res. II: Topical Studies in Oceanography 49(9), 1645-1674.

Ni, H.G., Lu, F.H., Luo, X.L., Tian, H.Y., Zeng, E.Y., 2008. Riverine inputs of total organic carbon and suspended particulate matter from the Pearl River Delta to the coastal ocean off South China. Mar. Poll. Bull. 56(6), 1150-1157.

Nichols, M.M., 1989. Sediment accumulation rates and relative sea-level rise in lagoons. Mar. Geol. 88(3), 201-219. 
Pondaven, P., Ragueneau, O., Tréguer, P., Hauvespre, A., Dezileau, L., Reyss, J.L., 2000.

Resolving the 'opal paradox' in the Southern Ocean. Nature 405(6783), 168-172.

Rabouille, C., Caprais, J.C., Lansard, B., Crassous, P., Dedieu, K., Reyss, J.L., Khripounoff, A., 2009. Organic matter budget in the Southeast Atlantic continental margin close to the Congo Canyon: In situ measurements of sediment oxygen consumption. Deep Sea Res. II: Topical Studies in Oceanography 56(23), 2223-2238.

Ragueneau, O., Tréguer, P., Leynaert, A., Anderson, R.F., Brzezinski, M.A., DeMaster, D.J., Dugdale, R.C., Dymond, J., Fischer, G., François, R., Heinze, C., Maier-Reimer, E., MartinJézéquel, V., Nelson, D.M., Quéguiner, B., 2000. A review of the Si cycle in the modern ocean: recent progress and missing gaps in the application of biogenic opal as a paleoproductivity proxy. Global Planet. Change 26(4), 317-365.

Ragueneau, O., Gallinari, M., Corrin, L., Grandel, S., Hall, P., Hauvespre, A., Lampitt, R.S., Rickert, D., Stahl, H., Tengber, A., Witbaard, R., 2001. The benthic silica cycle in the Northeast Atlantic: annual mass balance, seasonality, and importance of non-steady-state processes for the early diagenesis of biogenic opal in deep-sea sediments. Progress in Oceanogr. 50(1), 171-200.

Ragueneau, O., Dittert, N., Pondaven, P., Tréguer, P., Corrin, L., 2002. Si/C decoupling in the world ocean: is the Southern Ocean different?. Deep Sea Res. II: Topical Studies in Oceanography 49(16), 3127-3154.

Ragueneau, O., Savoye, N., Del Amo, Y., Cotton, J., Tardiveau, B., Leynaert, A., 2005. A new method for the measurement of biogenic silica in suspended matter of coastal waters : using Si :Al ratios to correct for the mineral interference. Cont. Shelf Res. 25(5-6), 697-710.

Ragueneau, O., Schultes, S., Bidle, K., Claquin, P., Moriceau, B., 2006. Si and C interactions in the world ocean: Importance of ecological processes and implications for the role of 
diatoms in the biological pump. Global Biogeochem. Cycles 20(4), DOI:

10.1029/2006GB002688.

Ragueneau, O., Regaudie-de-Gioux, A., Moriceau, B., Gallinari, M., Vangriesheim, A., Baurand, F., Khripounoff, A., 2009. A benthic Si mass balance on the Congo margin : Origin of the $4000 \mathrm{~m} \mathrm{DSi}$ anomaly and implications for the transfer of Si from land to ocean. Deep Sea Res. II: Topical Studies in Oceanography 56(23), 2197-2207.

Ragueneau, O., Conley, D.J., DeMaster, D.J., Dürr, H.H., Dittert, N., 2010. Biogeochemical transformations of silicon along the land-ocean continuum and implications for the global carbon cycle, in: Liu, K.-K., Aktinson, L., Quinones, R., Talaue-McManus, L. (Eds.), Carbon and Nutrient Fluxes in Continental Margins. Springer Berlin Heidelberg, Berlin, pp. 515-527.

Raimonet, M., 2011. Cycle benthique du silicium dans les estuaires : observations et expérimentations à différentes échelles spatio-temporelles. Ph.D. thesis, 179 pp.

Round, F.E., 1991. Diatoms in river water-monitoring studies. J. Appl. Phycol. 3, 129-145.

Savoye, B., Babonneau, N., Dennielou, B., Bez, M., 2009. Geological overview of the Angola-Congo margin, the Congo deep-sea fan and its submarine valleys. Deep Sea Res. II: Topical Studies in Oceanography 56(23), 2169-2182.

Sayles, F.L., Martin, W.R., Chase, Z., Anderson, R.F., 2001. Benthic remineralization and burial of biogenic $\mathrm{SiO} 2, \mathrm{CaCO}$, organic carbon, and detrital material in the Southern Ocean along a transect at $170^{\circ}$ West, Deep Sea Res. II: Topical Studies in Oceanography 48(1920), 4323-4383.

Schelske, C.L., Stoermer, E.F., 1971. Eutrophication, silica depletion, and predicted changes in algal quality in Lake Michigan. Science 173(3995), 423-424.

Seyler, P., Coynel, A., Moreira-Turcq, P., Etcheber, H., Colas, C., Orange, D., Bricquet, J.P., Laraque, A., Guyot, J.L., Olivry, J.C., Stewart, B.A., 2005. Organic carbon transported by the Equatorial rivers: example of Congo-Zaire and Amazon Basins, in: Roose, E.J., Lal, R., 
Feller, C., Barthès, B., Stewart, B.A. (Eds.), Soil erosion and carbon dynamics. CRC Press, Boca Raton, pp. 255-274.

Street-Perrott, F.A., Barker, P.A., 2008. Biogenic silica: a neglected component of the coupled global continental biogeochemical cycles of carbon and silicon. Earth Surf. Process. Landforms 33, 1436-1457.

Tréguer, P., Le Corre, P., 1975. Manuel d'analyse des sels nutritifs dans l'eau de mer : utilisation de l'auto-analyseur Technicon II. Université de Bretagne Occidentale, Brest.

Tréguer, P., Nelson, D.M., Van Bennekom, A.J., DeMaster, D.J., Leynaert, A., Quéguiner, B., 1995. The balance of silica in the world ocean: a re-estimate. Science 268, 375-379.

Tréguer, P.J., De La Rocha, C.L., 2013. The world ocean silica cycle. Annual Rev. Mar. Sci. $5,477-501$.

Van Bennekom, A.J., Fred Jansen, J.H., van der Gaast, S.J., van Iperen, J.M., Pieters, J., 1989. Aluminium-rich opal: an intermediate in the preservation of biogenic silica in the Zaire (Congo) deep-sea fan. Deep Sea Res. A. Oceanographic Research Papers 36(2), 173-190. Van Cappellen, P., Qiu, L., 1997a. Biogenic silica dissolution in sediments of the Southern Ocean. I. Solubility. Deep Sea Res. II: Topical Studies in Oceanography 44(5), 1109-1128. Van Cappellen, P., Qiu, L., 1997b. Biogenic silica dissolution in sediments of the Southern Ocean. II. Kinetics. Deep Sea Res. II: Topical Studies in Oceanography 44(5), 1129-1149. Van Cappellen, P., Dixit, S., van Beusekom, J., 2002. Biogenic silica dissolution in the oceans: Reconciling experimental and field-based dissolution rates. Global Biogeochem. Cycles 16, 23-1-23-10. 
Tables

Table 1. Sampled sediment cores name and location.

\begin{tabular}{clcccc}
\hline Site & Code & Abbreviation & Depth $(\mathrm{m})$ & Longitude $\left({ }^{\circ} \mathrm{E}\right)$ & Latitude $\left({ }^{\circ} \mathrm{S}\right)$ \\
\hline A & WACS-A-PL435-CT & PL435 & 4750 & 6.0321 & -6.4484 \\
A & WACS-A-RAP3 & RAP3 & 4740 & 6.0330 & 6.4542 \\
C & WACS-C-PL436-CT & PL436 & 4946 & 5.4886 & -6.7033 \\
C & WACS-C-PL437-CT & PL437 & 4946 & 5.4883 & -6.7014 \\
C & WACS-C-RAP4 & RAP4 & 4950 & 5.4837 & -6.6878 \\
D & WACS-D-PL438-CT & PL438 & 5028 & 5.1279 & -6.4755 \\
\hline
\end{tabular}

Table 2. Modelled benthic dSi fluxes $\left(\mathrm{mol} \mathrm{Si} \mathrm{m} \mathrm{y}^{-1}\right)$ at the sediment-water interface in the deep sea fan: diffusion, bioirrigation, and total fluxes. Modelled and measured total fluxes are compared.

\begin{tabular}{llcccc}
\hline Site & Code & Diffusion & Bioirrigation & \multicolumn{2}{c}{ Total dSi flux } \\
& & & & modelled & measured \\
\hline A & PL435-RAP3 & 0.06 & $0.18(74 \%)$ & $\mathbf{0 . 2 4}$ & $\mathbf{0 . 1 4 - 0 . 1 8}$ \\
C & PL436-RAP4 & 0.04 & $0.28(87 \%)$ & $\mathbf{0 . 3 2}$ & $\mathbf{0 . 0 8 - 0 . 3 4}$ \\
C & PL437 & 0.09 & $0.30(77 \%)$ & $\mathbf{0 . 3 8}$ & - \\
D & PL438 & 0.22 & $0.04(16 \%)$ & $\mathbf{0 . 2 7}$ & - \\
\hline & mean & $\mathbf{0 . 1 0}$ & $\mathbf{0 . 2 0}$ & $\mathbf{0 . 3 0}$ & \\
\hline
\end{tabular}

Table 3. Benthic mass balance of Si fluxes (mol Si m${ }^{-2} \mathrm{y}^{-1}$ ) in the deep sea fan, and comparison with other sites worldwide (from Ragueneau et al., 2009): BIOZAIRE sites C and $D$ to get estimates of the measured input fluxes in a close region, BATS to show an example of a budget that is closed in a 1D vision, and POOZ to compare with a site exhibiting the highest measured input flux to date. 


\begin{tabular}{lcccccc}
\hline & \multicolumn{9}{c}{ Atlantic Ocean } & & Southern Ocean \\
\cline { 2 - 5 } \cline { 6 - 7 } & $\begin{array}{c}\text { Congo } \\
\text { deep-sea } \\
\text { fan }\end{array}$ & BIOZAIRE/C & BIOZAIRE/D & $\begin{array}{c}\text { North West } \\
\text { (BATS) }\end{array}$ & POOZ \\
\hline aSiO $_{2}$ burial & $\mathbf{2 . 2 9}$ & 0.172 & 0.307 & 0.001 & & 0.42 \\
Diffusive dSi flux & $\mathbf{0 . 1 1}$ & 0.274 & 0.614 & 0.017 & & 2.03 \\
Bioirrigation flux & $\mathbf{0 . 1 9}$ & - & - & - & - \\
Total dSi flux & $\mathbf{0 . 3 0}$ & - & - & & - \\
Reconstructed input flux & $\mathbf{2 . 4}$ & 0.446 & 0.921 & 0.018 & & 2.45 \\
Measured input flux & - & 0.073 & 0.11 & 0.019 & & 0.51 \\
Preservation efficiency & $\mathbf{7 6 . 3}$ & 38.6 & 33.3 & 5.6 & & 17.1 \\
\hline
\end{tabular}




\section{Figure caption}

Figure 1. Map of the study area and sampling sites.

Figure 2. Temporal evolution of Si concentrations (black) and Al concentrations (grey) during the alkaline digestion of the first sediment slice of PL436 (Site C). Application of the four models of Köning et al. (2002). Points and lines represent data and model calculations, respectively.

Figure 3. Vertical profiles of $\mathrm{aSiO}_{2}$ concentrations (weigh \%) at the four stations, as measured following a modified version of Köning et al. (2002), see text for details. In this method, "Model 1" refers to a model with one phase of $\mathrm{aSiO}_{2}$ (in grey) and "Best adj." refers to the model that provides the best statistical adjustment to the data, typically model 2 or model 3 of Köning et al. (2002) (in black).

Figure 4. Vertical profiles of dSi concentrations $\left(\mu \mathrm{mol} \mathrm{I}^{-1}\right)$ in the pore waters of the deep-sea fan sediments.

Figure 5. Vertical profiles of $\mathrm{aSiO}_{2}$ and dSi concentrations in sediments at sites $\mathrm{A}, \mathrm{C}$ and D.

Points=data; Lines=model.

Figure 6. Temporal evolution of the quantity of matter of $\mathrm{dSi}$ per $\mathrm{m}^{2}$ in three benthic chambers (\#1, \#2 and \#3) at (A) Site A RAP3 and (B) Site C RAP4. 
Figure 1

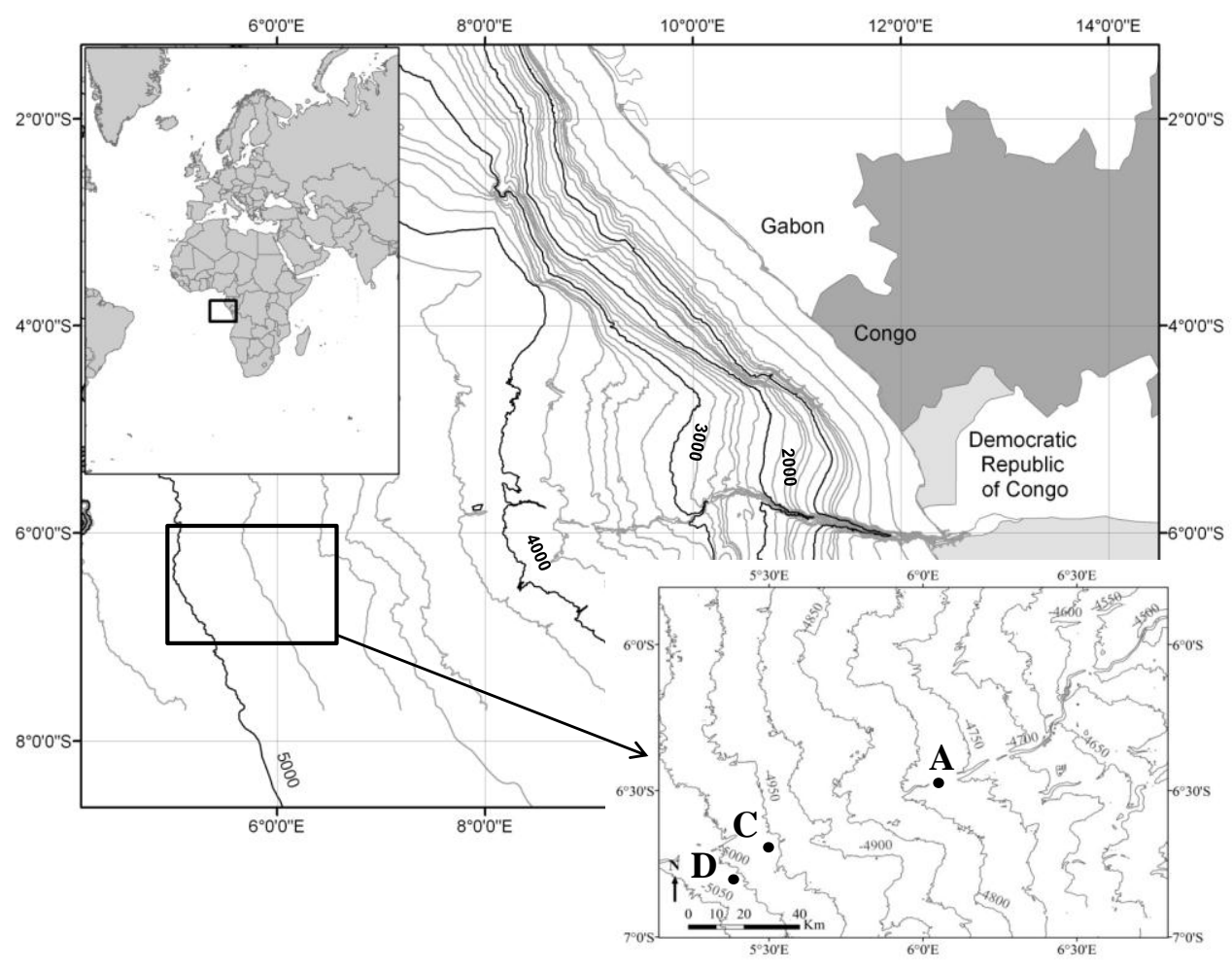


Figure2
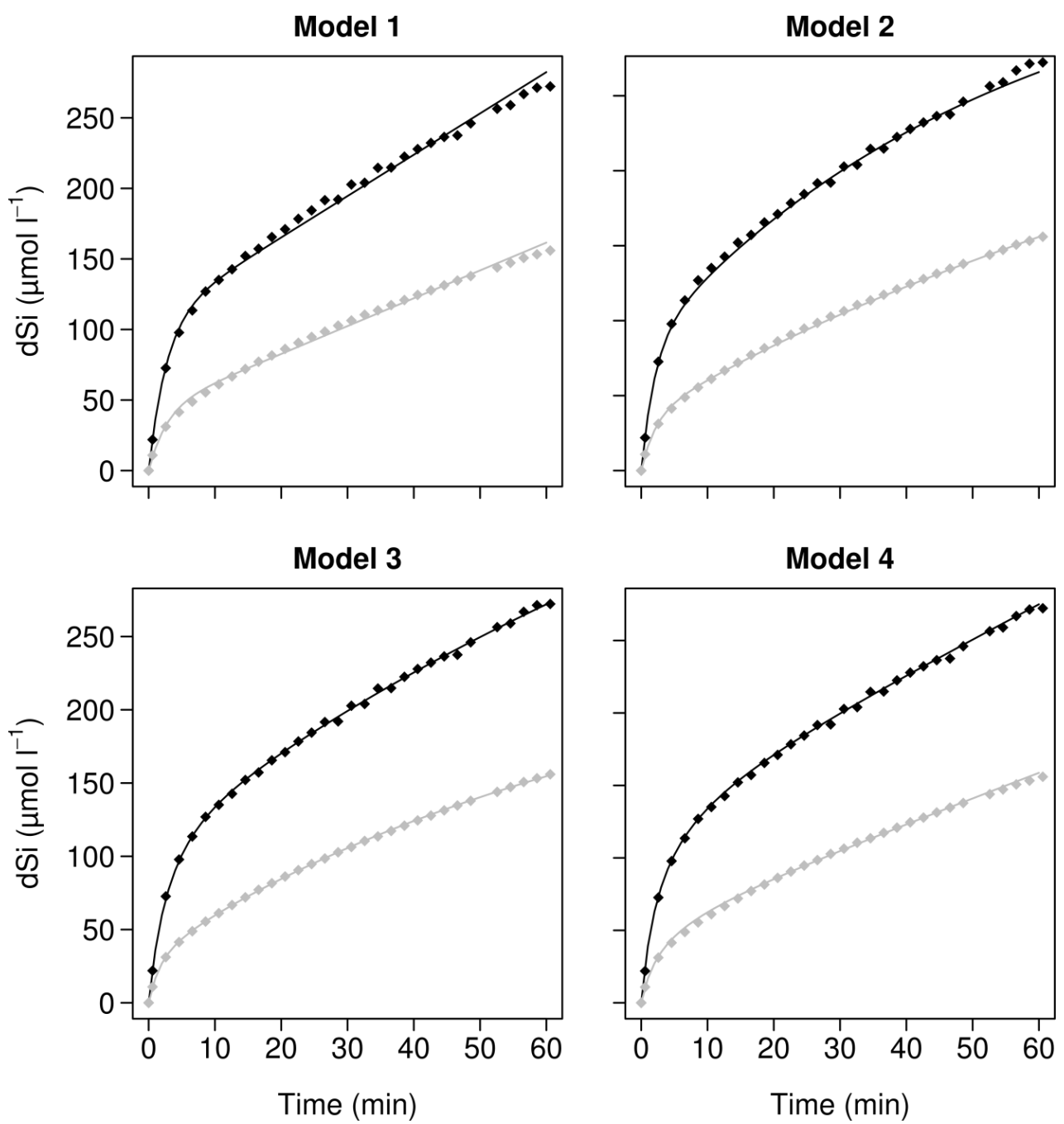
Figure 3
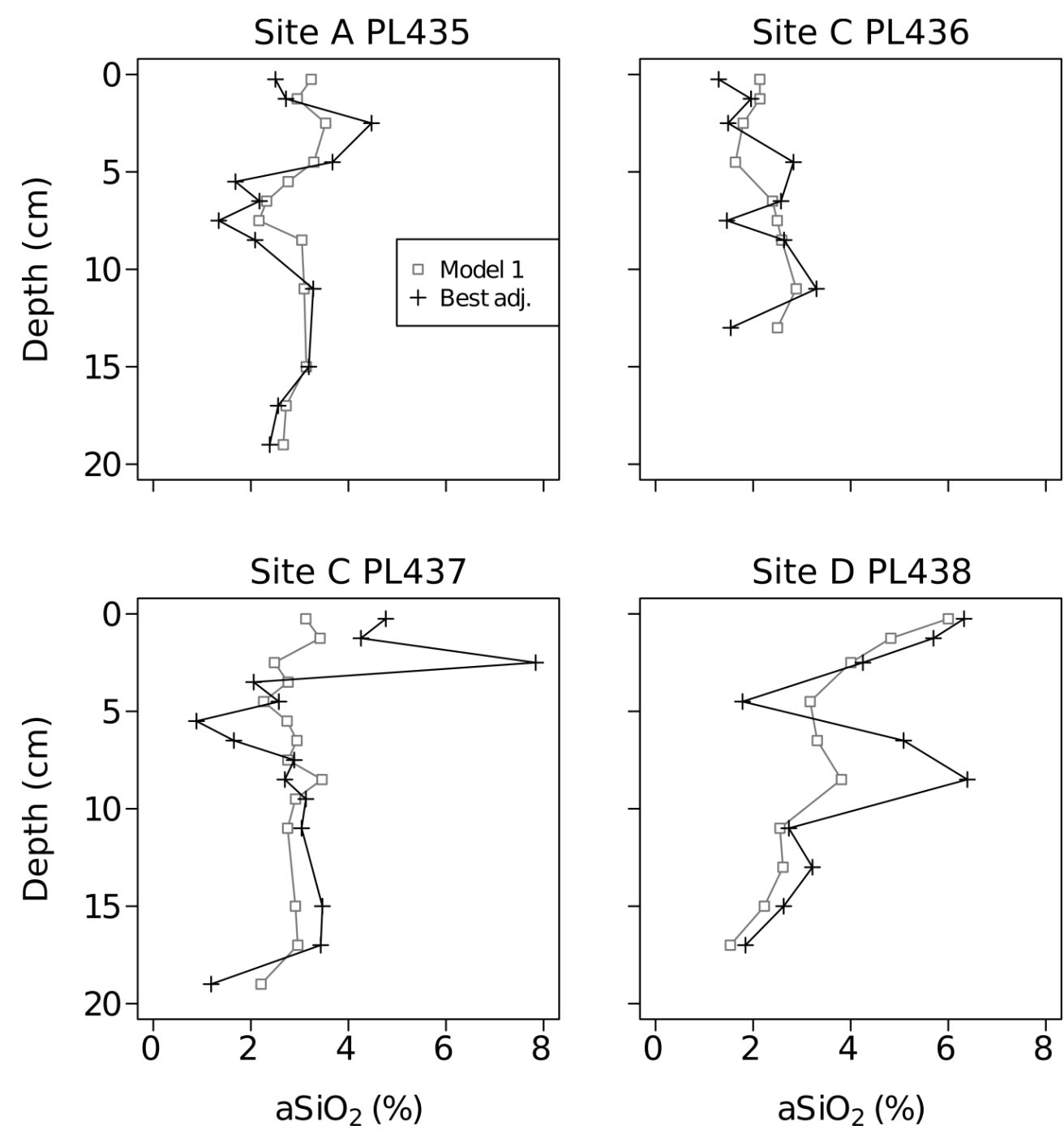
Figure 4

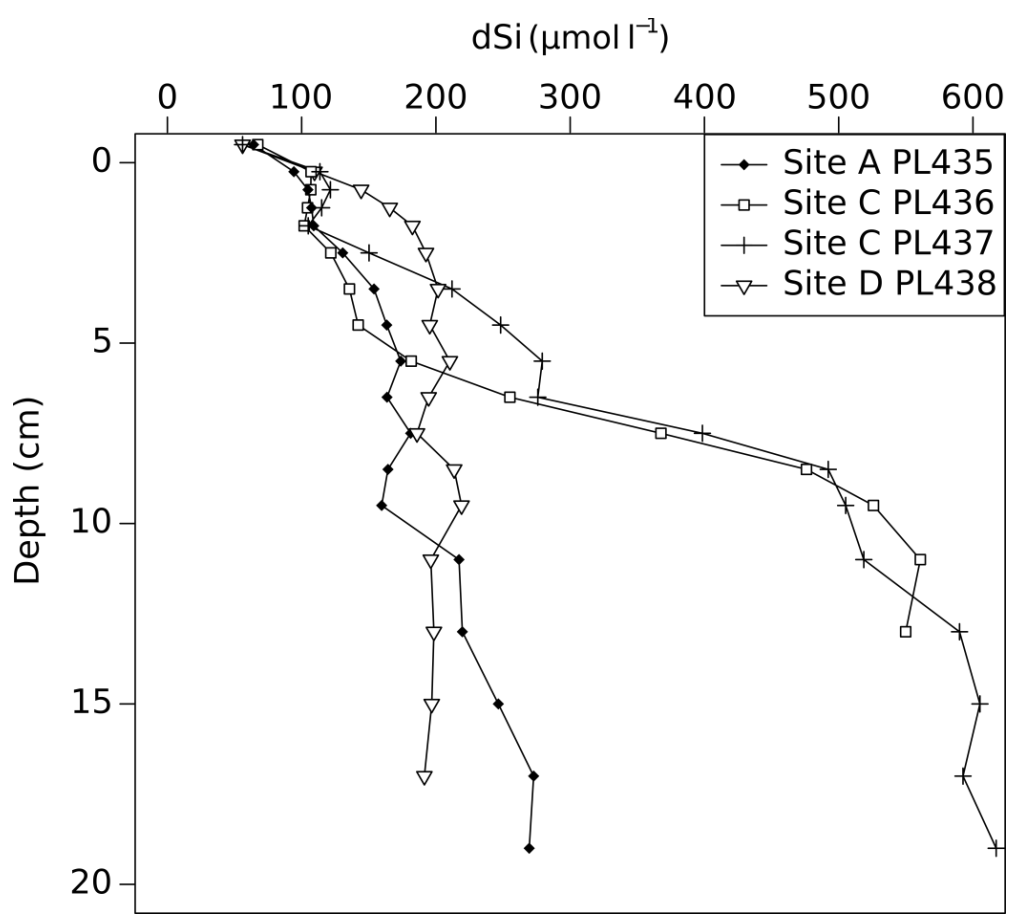


Figure 5
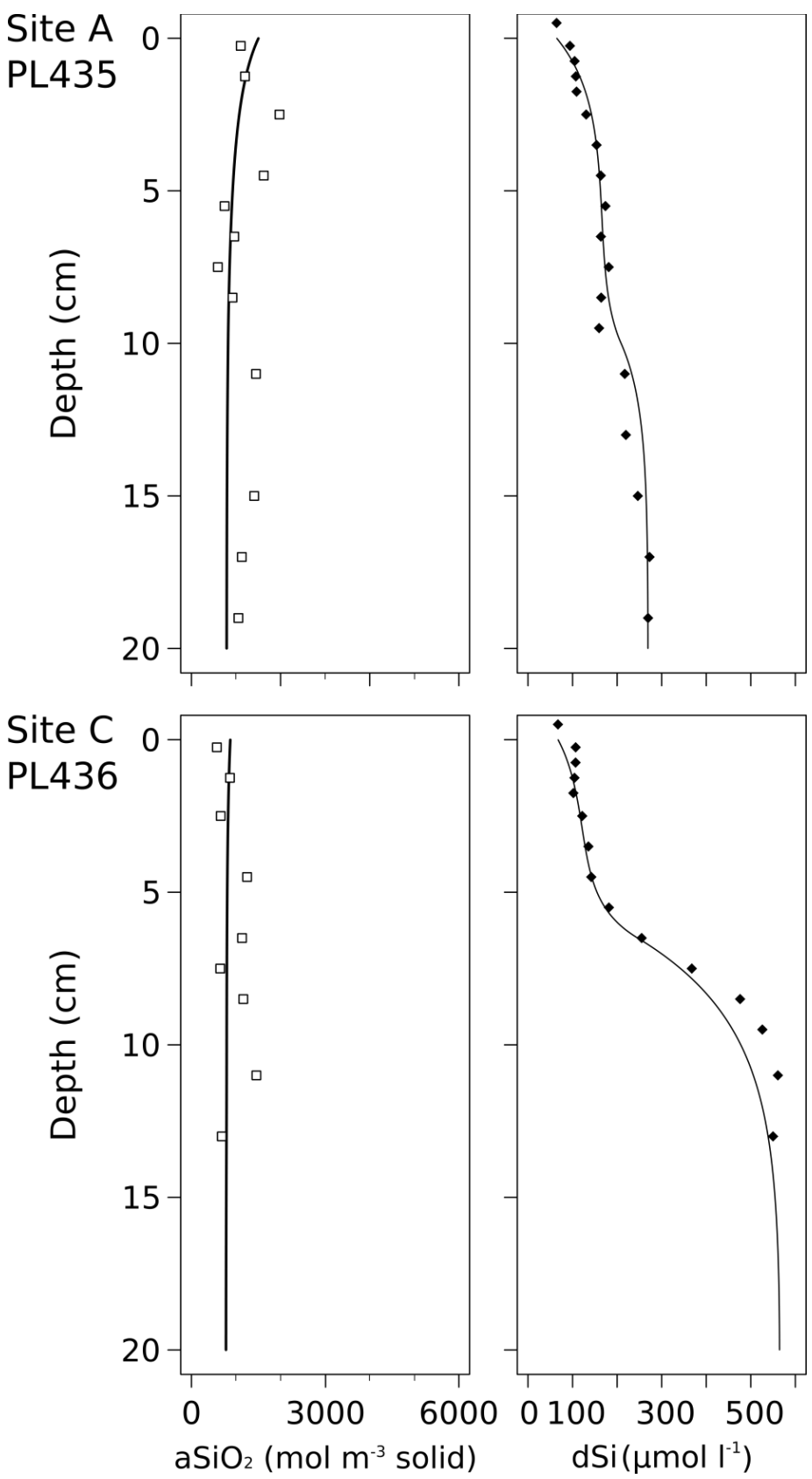

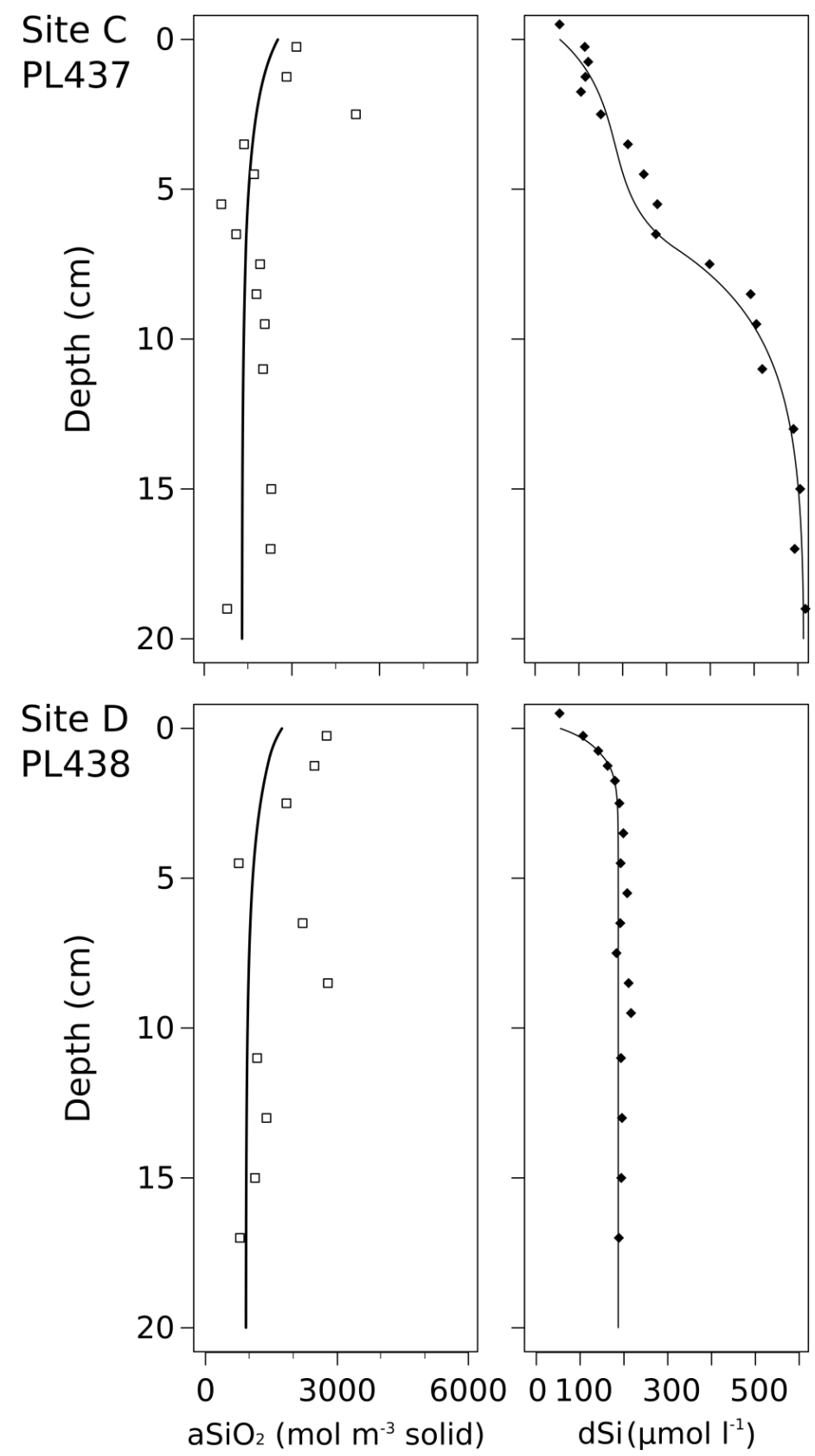
Figure 6
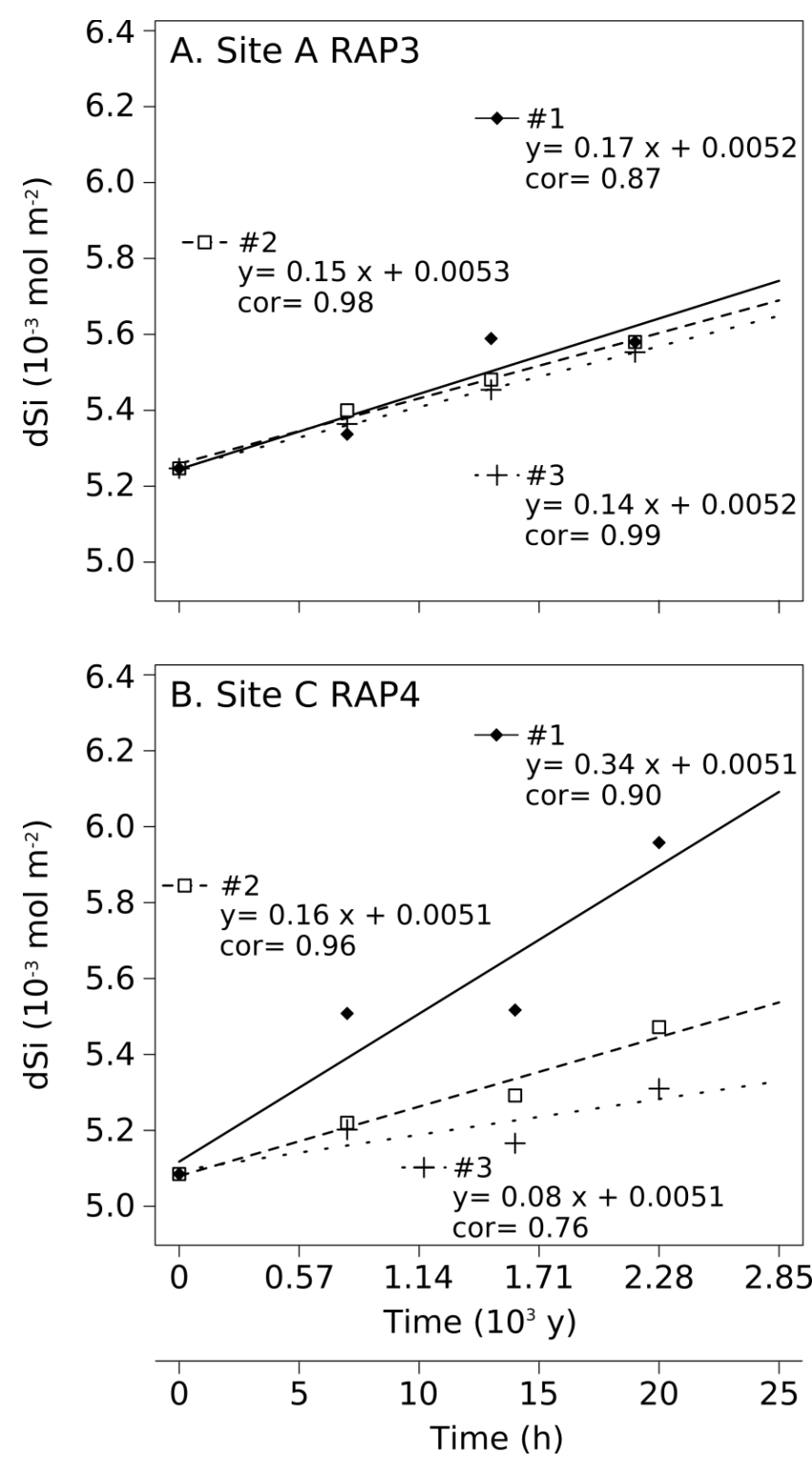